\title{
MUSHROOM TEA PRODUCTION TRAINING PACKAGE IN CAPACITY BUILDING PROGRAM TO INCREASE SMALL MEDIUM INDUSTRY (SME) ENTREPRENEURS IN RURAL
} \section{AREA}

\author{
Seri Chempaka Mohd. Yusof ${ }^{1}$ \\ Malaysian Nuclear Agency, Malaysia. \\ (Email: seri@ nuclearmalaysia.gov.my) \\ Azhar Mohamad ${ }^{2}$ \\ Malaysian Nuclear Agency, Malaysia. \\ (Email: azhar_m@nuclearmalaysia.gov.my) \\ Normazlin Ismail ${ }^{3}$ \\ Malaysian Nuclear Agency, Malaysia. \\ (Email: normazlin@nuclearmalaysia.gov.my) \\ Mohd. Fauzi Haris ${ }^{4}$ \\ Malaysian Nuclear Agency, Malaysia. \\ (Email: fauziharis@nuclearmalaysia.gov.my) \\ Ruzaimi Haron ${ }^{5}$ \\ Malaysian Innovation Foundation (Yayasan Inovasi Malaysia), Malaysia. \\ (Email: ruzaimi@yim.my) \\ Rasif Mohd. Zain ${ }^{6}$ \\ Malaysian Nuclear Agency, Malaysia. \\ (Email: rasif@nuclearmalaysia.gov.my) \\ Mohd. Hafiz Abdul Nasir ${ }^{7}$ \\ Malaysian Nuclear Agency, Malaysia. \\ (Email: mhafiz_an@nuclearmalaysia.gov.my)
}

Received date: 25-07-2019

Revised date: 20-08-2019

Accepted date: 17-09-2019

Published date: 18-09-2019

To cite this document: Yusof, S. C. M., Mohamad, A., Ismail, N., Haris, M. F., Haron, R., Zain, R. M., \& Nasir, M. H. A. (2019). Mushroom Tea Production Training Package in Capacity Building Program to Increase Small Medium Industry (SME) Entrepreneurs in Rural Area. International Journal of Entrepreneurship and Management Practices, 2 (7), 8092.

DOI: $10.35631 /$ ijemp.27009

Abstract: Volvariella tea is an innovative beverage of Malaysian Nuclear Agency that produced using Volvariella volvacea mushrooms with unique taste, aroma and has certain properties for health. This tea can be taken by everyone regardless of age and can be added 
in other beverages as a source of nutrients, vitamins and others to improve health. Currently, there have been efforts to grow mushrooms including Volvariella volvacea mushrooms based on the demand for diversity in dishes and awareness of the nutrients by taking mushrooms in daily meals. These mushrooms have short shelf life after harvesting time and need to be sold in fresh state and cannot stored in chiller for a longer time. Due to the vast volume of mushrooms obtained after harvest time, new product such as Volvariella tea is needed to be produced from these mushrooms to avoid any loss because of rotten mushrooms. Malaysian Nuclear Agency has collaborated with Malaysian Innovation Foundation (Yayasan Inovasi Malaysia) and PUSPANITA Nuclear Malaysia (The Association of Wives and Women Civil Servants Malaysia - Malaysian Nuclear Agency) to carry out the project - MSI 17110: Mushroom Tea Production Training Package in Capacity Building Program to Increase Small Medium Industry (SME) Entrepreneurs in Rural Area using MOSTI Social Innovation Fund (MSI).This project was carried out for 6 months in 2018 by transferring the production technology of Volvariella Tea to the community in the village of Rembang Panas, Juasseh, Kuala Pilah, Negeri Sembilan. A total of 25 participants consisted of farmers and rubber tappers were attended series of training on Volvariella volvacea mushrooms cultivation using selected strain seedling produced by Malaysian Nuclear Agency, intensive practical training on production of Volvariella tea and online marketing. Volvariella tea was processed via drying technique, packed in individual sachet and irradiated for decontamination process. The participants have managed to set up a company named as Syarikat Rembang Panas Jaya Outlet to carry out the production of Volvariella Tea, other downstream products and conducted the business of the Volvariella Tea products. A total of 125 people has benefited as the impact of the project. With these efforts, the product introduced can be used by community to generate additional income by mass producing and selling activities through online marketing.

Keywords: Mushroom, Innovative Beverage, Volvariella Volvacea, Training, Entrepreneur

\section{Introduction}

There is an increased effort in planting and producing mushrooms including Volvariella volvacea (Paddy Straw Mushroom) due to the demands for variety dishes and awareness of the people about the benefits in consuming mushrooms. Volvariella volvacea mushrooms or Tropical Button Mushroom is suitable for growing in Malaysia and this mushroom cultivation industry has great potential because of the high demand and short growth process. This mushroom is also capable in generating lucrative income to farmers on a continuous basis with low initial costs. Mushroom production throughout the year allows it to have good prospects in producing downstream products.

Due to the short shelf life after harvesting time, these mushrooms need to be sold in fresh state and cannot stored in a chiller for a longer time. The fresh mushrooms is marketed directly or used as a ready-made product. Vast volume of mushrooms obtained after harvest time and new product is needed to be produced from these mushrooms to avoid any losses because of rotten mushrooms (Intan Suhana, 2018). Volvariella tea is an innovative beverage of Malaysian Nuclear Agency that produced using Volvariella volvacea mushrooms. The innovation in utilizing the mushroom for drinking beverage is enable growers to make 
clearance on dumping of fresh mushroom in market. The tea has a good aromatic smell and special taste which is unique, and privilege as low temperature process was applied in controlling the quality. This tea can be consumed by everybody and suitable for every age not only as addition of variety in drinks but also as a source for gaining nutrients, vitamins and others for the wellness of health.

V. volvacea has its own properties of good sources of vitamin B including riboflavin, niacin and pantothenic acid. These properties are important for nervous system, blood cells, healthy skin and also are important in breaking proteins, fats and carbohydrate (Rop et al., 2009). Studies carried out showed some benefits of $V$. volvacea are related to:

a) Weight loss and diet management - maintain blood sugar level, soluble fibers for increasing digestion, reducing body heat, promotes body fluid (Poonam et al. 2014)

b) Boost uptake of the nutrient content in the body (Poonam et al. 2014)

c) Healing function of hypertension, lowering blood pressure and cholesterol levels in our body (Roy et al. 2014)

d) Potent anti-inflammatory characteristics that may be helpful for those suffering from asthma, rheumatoid arthritis, renal failure and stroke damage (Roy et al. 2014)

e) Source of vitamins and mineral - high solubility diet quality and improved nutrition (Rop et al. 2009)

f) Antioxidant properties - effective in removing free radicals from our body and improved the immunity (Ramkumar et al. 2012)

g) Skin care moisture for cosmeceutical values related to stimulating skin collagen (Ruksiriwanich et al. 2014).

V. volvacea is a good source of polypeptides, terpenes, steroids (Shwetha and Sudha, 2012) and phenolic compounds such as flavonoids, phenolic acid and tannins which contribute to high antioxidant capacity. Hung and Nhi (2012) found that the free phenolics are higher in the V.volvacea which are the major contributor to the antioxidant activity. Similarly, the present investigation also shows the presence of biochemical compounds like alkaloids, terpenoids, phenol, tannin, sugar, saponin, flavonoids, protein and steroids in both the species of $V$. volvacea and Volvariella bombycina.

Malaysian Nuclear Agency has collaborated with Malaysian Innovation Foundation (Yayasan Inovasi Malaysia) and PUSPANITA Nuclear Malaysia (The Association of Wives and Women Civil Servants Malaysia - Malaysian Nuclear Agency) to carry out the project - MSI 17110: Mushroom Tea Production Training Package in Capacity Building Program to Increase Small Medium Industry (SME) Entrepreneurs in Rural Area using MOSTI Social Innovation Fund (MSI). This project was implemented by transferring the production technology of Volvariella Tea to the community in the village of Rembang Panas, Juasseh, Kuala Pilah, Negeri Sembilan. This project was proceed using similar method from previous project titled - MSI 16011: Ginseng and Tongkat Ali Innovative Chocolate Production Training in Capacity Building Program to Increase Small Medium Industry (SME) Entrepreneurs (Seri et al, 2019).

This was an effort to help communities to increase their income by producing it as a selling product that pertinent to production process that is easy and does not require a lot and 
expensive equipment and materials. The target community of this project was farmers and rubber tappers. The objective of this project was to provide intensive training on $V$. volvacea mushrooms cultivation using selected strain seedling produced by Malaysian Nuclear Agency, intensive practical training on production of Volvariella tea and online marketing to the community group in an effort to build-up an attempt to increase sources of income of the communities and as encouragement to become SME (Small and Medium Industry) entrepreneurs.

\section{Methodology}

This project was carried out by the staffs of Malaysian Innovation Foundation (Yayasan Inovasi Malaysia), Malaysian Nuclear Agency and PUSPANITA Nuclear Malaysia using MOSTI Social Innovation Fund as to increase sources of income of the community in the village of Rembang Panas, Juasseh, Kuala Pilah, Negeri Sembilan and as encouragement to become SME (Small and Medium Industry) entrepreneurs. The project activities were carried out in 6 months period during year 2018 as followed to the milestone involved (Table 1).

The tasks were executed as mentioned below:

a) A group consisting of staffs of Malaysian Nuclear Agency and Malaysian Innovation Foundation (Yayasan Inovasi Malaysia) was formed to carry out specific tasks in the project. Meetings were held from time to time to monitor the progress of the activities in the project and to resolve problems arise in executing the tasks. The purchasing and preparation of facilities, equipment, raw materials, training kits and other related services were done before the trainings begun using the fund given.

b) The staffs were divided into two groups, namely, a group conducting trainings on $V$. volvacea mushrooms cultivation and Volvariella tea production and the second group conducting online business and marketing training.

Table 1: Milestone of The Project Activities Regarding the Duration Time for Each Activities

\begin{tabular}{|l|c|c|c|c|c|c|}
\hline Activities & $\begin{array}{c}\text { Month } \\
1\end{array}$ & $\begin{array}{c}\text { Month } \\
2\end{array}$ & $\begin{array}{c}\text { Month } \\
3\end{array}$ & $\begin{array}{c}\text { Month } \\
4\end{array}$ & $\begin{array}{c}\text { Month } \\
5\end{array}$ & $\begin{array}{c}\text { Month } \\
6\end{array}$ \\
\hline $\begin{array}{l}\text { Determination of project team and } \\
\text { participants }\end{array}$ & & & & & & \\
\hline $\begin{array}{l}\text { Purchasing of equipment, raw } \\
\text { materials and training kits }\end{array}$ & & & & & & \\
\hline $\begin{array}{l}\text { Upgrading the facility - workshop } \\
\text { house for Volvariella tea production }\end{array}$ & & & & & & \\
\hline $\begin{array}{l}\text { Preparation of training kits and } \\
\text { facilities }\end{array}$ & & & & & & \\
\hline $\begin{array}{l}\text { Training on cultivation of V. volvacea } \\
\text { mushrooms }\end{array}$ & & & & & & \\
\hline Training on Volvariella tea production & & & & & & \\
\hline Training of online business and & & & & & \\
\hline
\end{tabular}




\begin{tabular}{|l|l|l|l|l|l|l|}
\hline marketing of Volvariella tea & & & & & & \\
\hline Skill monitoring in handling & & & & & & \\
communication networks with public & & & & & & \\
using online medium such as & & & & & & \\
Facebook, Tweet and Blog & & & & & & \\
\hline Preparation of project report & & & & & \\
\hline
\end{tabular}

The production of the Volvariella tea in this training was based on the formulation of Volvariella tea that contains dried $V$. volvacea mushrooms. The dried $V$. volvacea mushrooms were prepared using Standard Operating Procedure (SOP) of - Process of Drying Mushroom: Volvariella volvacea (Azhar and Seri Chempaka, 2018).

The training of $V$. volvacea mushrooms cultivation was carried out in prepared area in Kampung Rembang Panas gradually for 3-4 months. The training of production of Volvariella tea was carried out in the upgraded workshop house facility in Kampung Rembang Panas for 2 days. For this training, each participant was given a note book and a manual book for processing mushroom tea (Seri et al. 2018). The hands-on training was conducted using Manual Book of Producing Volvariella tea (Seri Chempaka et al, 2018). The training of online business and marketing was carried out in Malaysian Nuclear Agency. For training of $V$. volvacea mushrooms cultivation, each participant was given planting kit and a book on mushroom cultivation (Azhar et al, 2018) and the process was described briefly in Table 2. For online business and marketing training, each participant was given a note book, handouts, a thumbdrive and online sale guide books. Training modules on production of Volvariella tea and on online business and marketing for Volvariella tea were developed using references (Bruhad, 2009; Newstrainers.wordpress.com, 2009). The trainings were carried out using training modules that briefly described in Table 3 and Table 4.

Table 2: Process Sequences of Cultivation of $V$. Volvacea Mushrooms

\begin{tabular}{|l|l|}
\hline & Process of cultivation of Volvariella volvacea mushrooms \\
\hline 1) Day 1-10 & $\begin{array}{l}\text { Composting EFB (empty fruit bunches of oil palm tree). Watering every } 2 \\
\text { days interval for 3 times }\end{array}$ \\
\hline 2) Day 11-20 & $\begin{array}{l}\text { Spawning Process. Prepare bedding prior to sowing V. volvacea substate } \\
\text { seedling. Use plastic sheet to complete tight covered the bed. }\end{array}$ \\
\hline 3) Day 21-30 & $\begin{array}{l}\text { Pinning process. Bring up the plastic sheet to completely loose the cover for } \\
\text { air circulation. }\end{array}$ \\
\hline 4) Day 31-51 & $\begin{array}{l}\text { Fruiting Process. Ready for harvesting. There are six stages in maturing the } \\
\text { fruiting body - spawn, pin head, small button, egg, elongation, matured. }\end{array}$ \\
\hline
\end{tabular}


Table 3: Training Modules on Production of Volvariella Tea

\begin{tabular}{|c|c|c|}
\hline Time & Content/activity & Materials \\
\hline $10 \mathrm{~min}$ & $\begin{array}{l}\text { Briefing on sanitation in working area, utensils, } \\
\text { equipment, storage of raw materials, drying of } \\
\text { mushrooms, processing of Volvariella tea and } \\
\text { packaging of finished products }\end{array}$ & $\begin{array}{l}\text { Briefing slides, LCD } \\
\text { projector, LCD projector } \\
\text { screen }\end{array}$ \\
\hline $30 \mathrm{~min}$ & $\begin{array}{l}\text { Practices on handling related tools and equipment } \\
\text { in drying of mushrooms, processing of Volvariella } \\
\text { tea and packaging of finished products }\end{array}$ & Equipment and utensils \\
\hline 2 hours & $\begin{array}{l}\text { Practices on the process of the drying of } \\
\text { mushrooms in a clean, acceptable state and gets a } \\
\text { good quality product and meets the standards. }\end{array}$ & $\begin{array}{l}\text { Raw materials, equipment, } \\
\text { utensils, manual book }\end{array}$ \\
\hline 2 hours & $\begin{array}{l}\text { Exposed to various important steps in processing of } \\
\text { Volvariellatea including proper and accurate } \\
\text { weighing of the materials, the use of tools, utensils } \\
\text { and equipment, proper handling and storage of raw } \\
\text { materials and the finished products, the sanitary of } \\
\text { the personnel, the processing spaces and storage } \\
\text { areas. }\end{array}$ & $\begin{array}{l}\text { Raw materials, equipment, } \\
\text { utensils, manual book }\end{array}$ \\
\hline 2 hours & $\begin{array}{l}\text { Practices on the processing of Volvariella tea and } \\
\text { packaging of finished products in a clean, } \\
\text { acceptable state and gets a good quality product and } \\
\text { meets the standards. }\end{array}$ & $\begin{array}{l}\text { Raw materials, equipment, } \\
\text { utensils, manual book }\end{array}$ \\
\hline 2 hours & $\begin{array}{l}\text { Practices on preparing tea sachets, boxes, container } \\
\text { handling and storage methods. }\end{array}$ & $\begin{array}{l}\text { Packaging materials, tea } \\
\text { sachets, plastic casings, } \\
\text { boxes }\end{array}$ \\
\hline
\end{tabular}

Table 4: Training Modules on Online Business and Marketing for Volvariella Tea

\begin{tabular}{|c|l|l|}
\hline Time & \multicolumn{1}{|c|}{ Content/activity } & \multicolumn{1}{|c|}{ Materials } \\
\hline 15 min & $\begin{array}{l}\text { Briefing on handling the computer, internet, } \\
\text { creating marketing blog, Facebook, Instagram and } \\
\text { Tweet }\end{array}$ & $\begin{array}{l}\text { Briefing slides, LCD } \\
\text { projector, LCD projector } \\
\text { screen }\end{array}$ \\
\hline 2 hours & $\begin{array}{l}\text { Practices on handling the computer, internet, } \\
\text { creating marketing blog, Facebook, Instagram and } \\
\text { Tweet. The participants were trained intensively on } \\
\text { writing sentences, uploading pictures and handling } \\
\text { communication networks with public using online } \\
\text { how to start creating } \\
\text { marketing blog, Facebook, } \\
\text { Instagram, Tweet and } \\
\text { handling the computer and } \\
\text { internet. }\end{array}$ \\
\hline hour & $\begin{array}{l}\text { Practices on conducting online sales, accounting } \\
\text { and product deliveries. This training introduced } \\
\text { steps on handling online sales including } \\
\text { advertising, communication with buyers, handling }\end{array}$ & $\begin{array}{l}\text { Computer, note book, } \\
\text { pendrive, online sale guide } \\
\text { book (Miliza, 2016) }\end{array}$ \\
\hline
\end{tabular}




\begin{tabular}{|l|l|l|}
\hline $30 \mathrm{~min}$ & $\begin{array}{l}\text { orders and emphasized on deliveries, payments and } \\
\text { receipts. }\end{array}$ & \\
\hline $\begin{array}{l}\text { Briefing on professional way of doing online } \\
\text { business especially in entrepreneurial aspects, } \\
\text { marketing management and business plan } \\
\text { preparation. }\end{array}$ & $\begin{array}{l}\text { Briefing slides, LCD } \\
\text { projector, LCD projector } \\
\text { screen, online business } \\
\text { guide book (Umar, 2016) }\end{array}$ \\
\hline
\end{tabular}

\section{Results and Discussion}

A total of 25 participants from village of Rembang Panas, Juasseh, Kuala Pilah, Negeri Sembilan (farmers and rubber tappers) were attended series of training on Volvariella volvacea mushrooms cultivation using selected strain seedling produced by Malaysian Nuclear Agency, intensive practical training on production of Volvariella tea and online marketing (Figure 1, 2, 3 and 4). Table 5 showed the summary of the output gained from the project. Results from this project showed a few outcomes can be gained and became impacts of the project not only to the communities but also to the agency. One of the important outcomes was new entrepreneurs among farmers and rubber tappers and low-income groups were established. With this project, at the beginning approximately 125 people get the benefits and will be increasing after a few years. This community had the opportunity to venture into business with minimal capital, easier way in marketing products through online without the need for rental shops. Another outcome was training modules for $V$. volvacea mushrooms cultivation using selected strain seedling produced by Malaysian Nuclear Agency, intensive practical training on production of Volvariella tea and online marketing. These training modules can be used continuously by the agency to train other communities to develop entrepreneurs and commercialized the products. Commercialization of the product not only leads to cooperation with big companies but with online marketing and direct sales by these new entrepreneurs can also reached to local and foreign markets.

Table 5: Summary of The Output Gained from The Project

\begin{tabular}{|l|l|l|}
\hline Num. & $\begin{array}{l}\text { Project - MSI 17110: Mushroom Tea Production Training Package in Capacity } \\
\text { Building Program to Increase Small Medium Industry (SME) Entrepreneurs in Rural } \\
\text { Area }\end{array}$ & $\begin{array}{l}\text { Kampung Rembang Panas, Juasseh, Kuala Pilah, Negeri } \\
\text { Sembilan }\end{array}$ \\
\hline 1 & Place & $\begin{array}{l}\text { Main products: } \\
\text { products produced } \\
\text { a)Volvariella Tea Natural } \\
\text { b) Volvariella Tea Creamer }\end{array}$ \\
\hline 2 & $\begin{array}{l}\text { Downstream products: } \\
\text { a) Mushroom noodles } \\
\text { b) Mushroom snacks }\end{array}$ \\
\hline 3 & facilities developed & $\begin{array}{l}\text { a) Facility - 1: Workshop house for production of Volvariella } \\
\text { Tea and downstream mushroom products } \\
\text { b) Inovation - 1: Model of cultivation of Volvariella volvacea on } \\
\text { shelves using EFB (empty fruit bunches of oil palm tree). }\end{array}$ \\
\hline
\end{tabular}




\begin{tabular}{|l|l|l|}
\hline & & $\begin{array}{l}\text { c) A company was set up named as Syarikat Rembang Panas } \\
\text { Jaya Outlet to carry out the production of Volvariella Tea, } \\
\text { other downstream products and conducted the business of the } \\
\text { Volvariella Tea products }\end{array}$ \\
\hline 4 & $\begin{array}{l}\text { Trainings carried } \\
\text { out }\end{array}$ & $\begin{array}{l}\text { a) Training on V. volvacea mushrooms cultivation using selected } \\
\text { strain seedling produced by Malaysian Nuclear Agency on the } \\
\text { ground and shelves. } \\
\text { b) Intensive practical training on production of Volvariella tea } \\
\text { c) Training on online marketing and selling of Volvariella tea } \\
\text { and downsteam mushroom products. }\end{array}$ \\
\hline 5 & $\begin{array}{l}\text { Number of people } \\
\text { involved }\end{array}$ & $\begin{array}{l}\text { A total of 25 participants consisted of farmers and rubber tappers } \\
\text { were attended series of trainings. A total of 125 people has } \\
\text { benefited as the impact of the project. }\end{array}$ \\
\hline
\end{tabular}

Through this project, comprehensive training provided based on the training modules gave an opportunity for knowledge enhancement for the community and they will be able to increase their household income and a few benefits achieved were recognized such as:

a) The increase of entrepreneurs among farmers and low-income groups lead to increment of income from RM20/day to the range RM50/day from selling mushrooms and products through direct and online selling.

b) Increasing numbers of trainers for cultivation of mushrooms, product processing, entrepreneurship training and online business and marketing.

c) Created new sub industries - supplies of fresh mushrooms, mushroom tea and other mushroom based products.

d) The participants have managed to set up a company named as Syarikat Rembang Panas Jaya Outlet to carry out the production of Volvariella Tea, other downstream products and conducted the business of the mushrooms and downstream products.

The sustainability of the project was expected to include:

a) The training modules can be applied to the other community to form new entrepreneurs colloboration with Agriculture Department, National PUSPANITA (PUSPANITA ministries and other states), disabled people associations-200,000 target disabled people registered in the Department of Social Welfare (JKM) and other agricultural associations.

b) "Train the trainers" - attendees who are capable of controlling workshops and training (multiplier effects).

c) Interested companies to market the downstream mushroom products collaborated with Syarikat Rembang Panas Jaya Outlet.

d) Interested participants in cultivation of other type of mushrooms that have high demands.

\section{Conclusion}

Knowledge and skills gained enabled the community to move forward to increase the income of the community by cultivation of the mushrooms, producing the products and using technologies available. This project was an example showing the ability of a research institution in increasing the income of the community using the products and technologies 
available. Commercialization of the products to local community can improve the economy of the country by raising the socio-economic of the people.

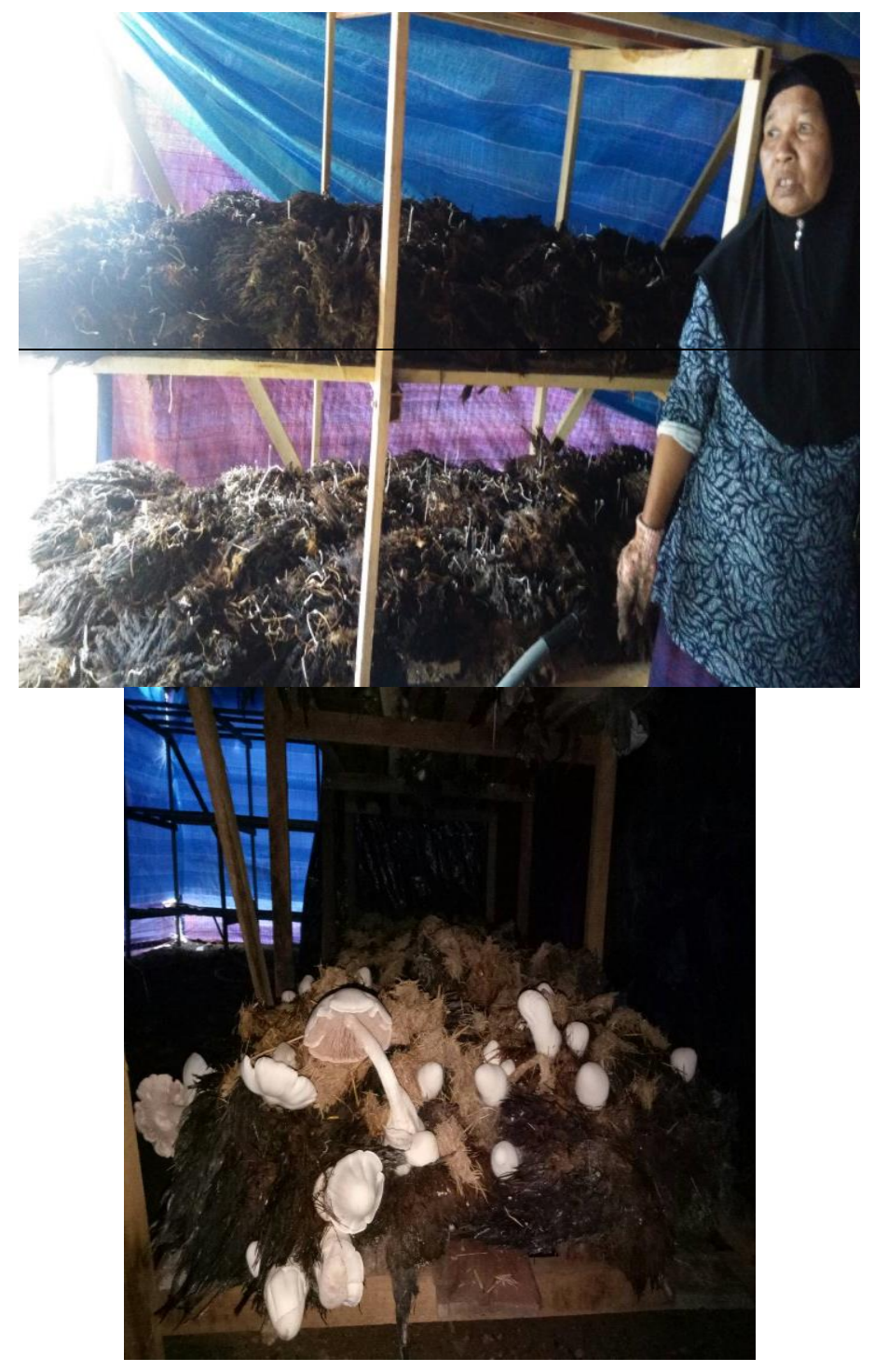

Figure 1: Training on Cultivation of Volvariella Volvacea Mushrooms 

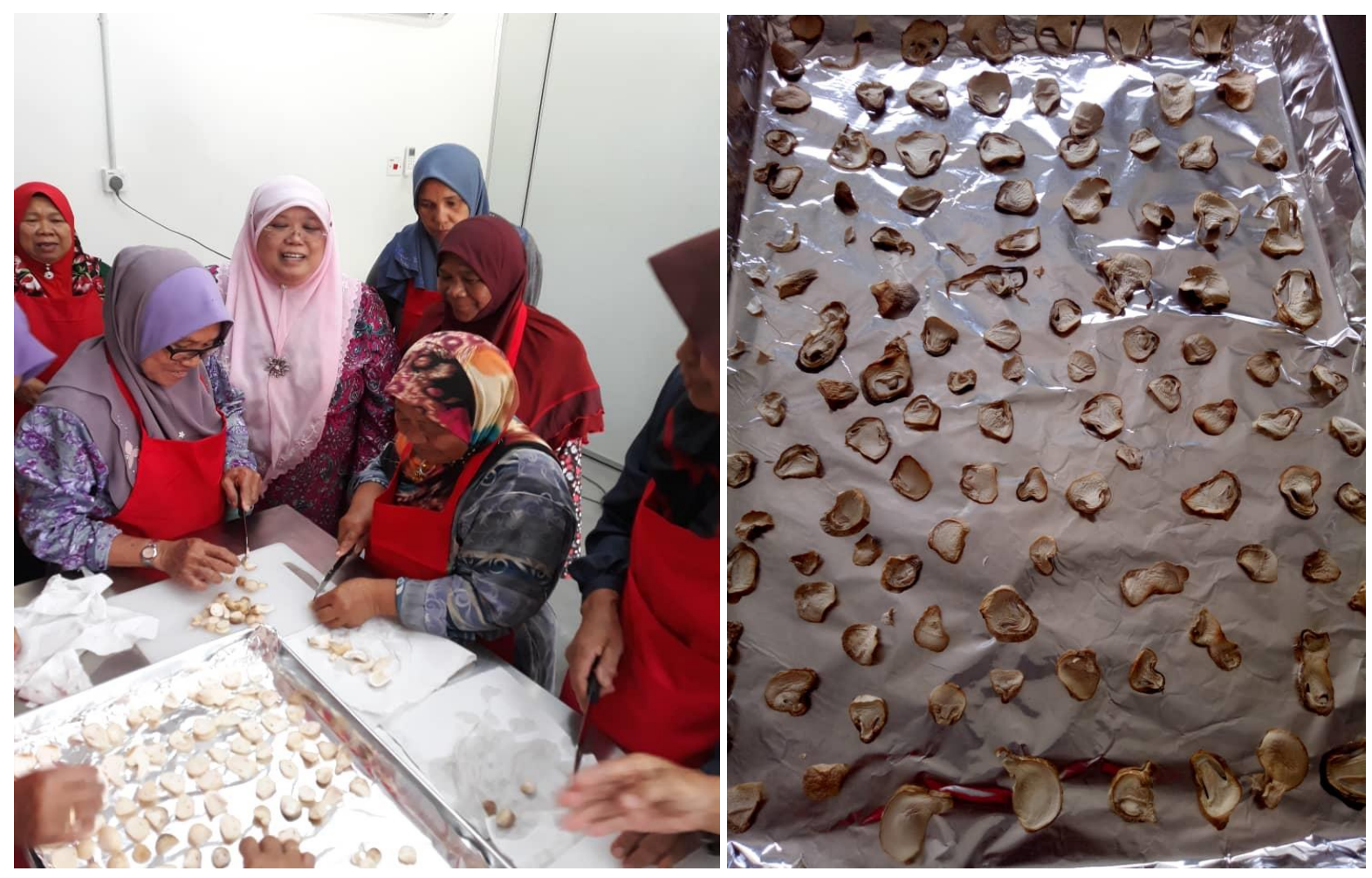

Figure 2: Training on Drying the Volvariella Volvacea Mushrooms 


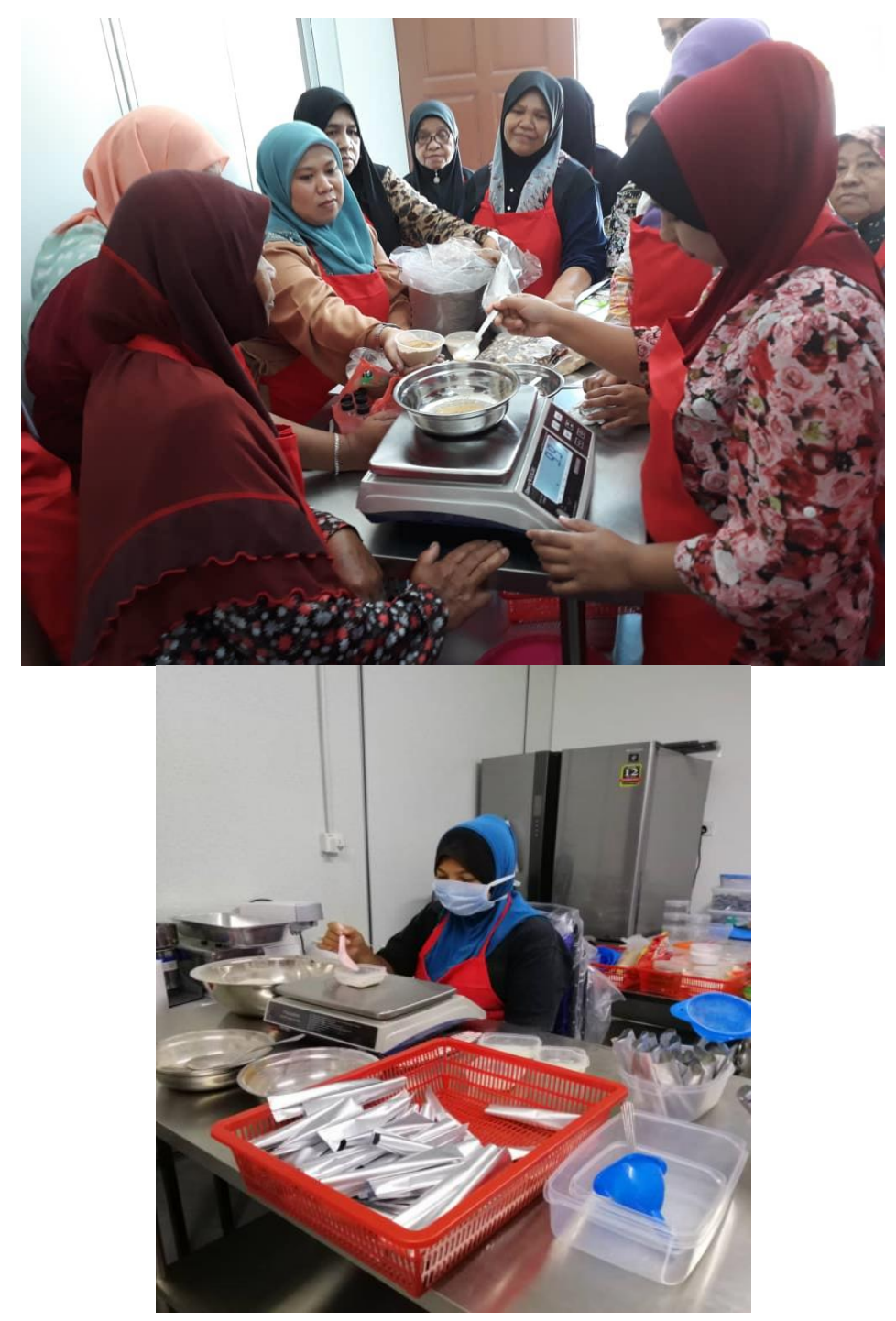

Figure 3: Training on Volvariella Tea Production 


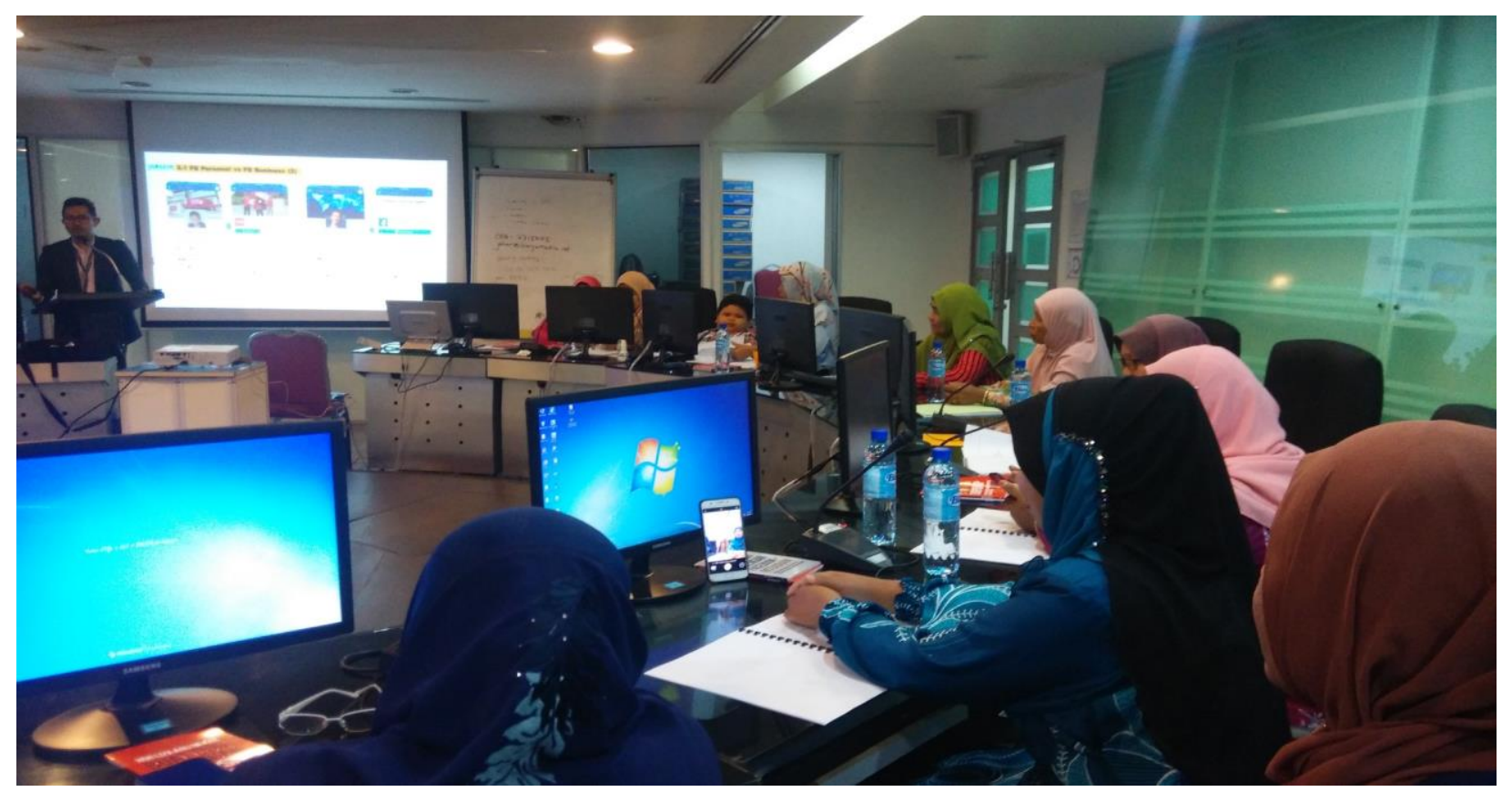

Figure 4: Training on Online Business and Marketing of Volvariella Tea

\section{References}

Azhar, M. and Seri Chempaka, M. Y. (2018). Standard Operating Procedure (SOP) - Process of Drying Mushroom: Volvariella volvacea. NUKLEARMALAYSIA/M/2018/31(S).

Azhar, M., Mohamad, Y. A. and Nur Hafizah, S. (2018) Teknologi Penanaman Cendawan Volvariella. Agensi Nuklear Malaysia. ISBN 978-967-9970-54-58.

Bruhad, B. (2009). How to prepare a basic training module. https://www.slideshare.net/bruhad/how-to-prepare-a-basic-training-module

Hung, P.V. and Nhi, N.N.Y. 2012. Nutritional composition and antioxidant capacity of several edible mushrooms grown in the Southern Vietnam. International Food Research Journal, 19(2): 611-615.

Intan Suhana, C. O. (2018). Teknologi nuklear keringkan cendawan. Ruangan Mega Sains, Utusan Malaysia. Ms. 16.

Miliza, G. (2016). Buat Duit Dengan Facebook Dan Instagram. PTS Publising House. Malaysia. ISBN-13:978-967-411-821-1.

Newstrainers.wordpress.com (2009). How to build a training module, Part 3. https://newstrainers.wordpress.com/2009/11/17/how-to-build-a-training-module-part3

Poonam, B., Ranjana, P. and Tejo Prakash, N. (2014). Enhanced antioxidant properties as a function of selenium uptake by edible mushrooms cultivated on selenium-accumulated waste post-harvest wheat and paddy residues. Int. J. Recyc.l Org. Waste Agricult., 3:127-132

Ramkumar, L., Ramanathan, T. and Johnprabagaran, J. (2012). Evaluation of nutrients, trace metals and antioxidant activity in Volvariella volvacea (Bull. Ex. Fr.) Sing. Emir. J. Food Agric., 24 (2): 113-119 
Rop O., Mlcek J. and Jurikova T. (2009). Beta Glucan in higher fungi and their health effects. Nutrition Reviews, 67:624-631

Roy, A., Prasad, P. and Gupta, N. (2014). Review Article. Volavriela volvaceae: A Macrofungus having nutritional and health potential. Asian J. Pham. Tech., 4(2)110113

Ruksiriwanich W. et al. (2014). Potent In Vitro Collagen Biosynthesis Stimulating and Antioxidant Activities of Edible Mushroom Volvariella Volvacea Aqueous Extract. Int. J. Pharm. Sci., 6(2)2, 406-412.

Seri Chempaka, M. Y., Azhar, M. and Normazlin, I. (2018). Manual Book of Processing Mushroom Tea. Malaysian Nuclear Agency.

Seri Chempaka, M. Y., Normazlin, I., Mohd. Fauzi, H., Sobri, H. and Mohd. Suhaimi, J. (2019). Bioreactor Downstream Product Technology Transfer - Ginseng and Tongkat Ali Innovative Chocolate Production Training in Capacity Building Program to Increase Small Medium Industry (SME) Entrepreneurs. Journal of Information System and Technology Management. Volume: 4 Issues: 11 [March 2019] pp.22-33]. eISSN: 0128-6666.

Shwetha, V.K. and Sudha, G.M. 2012. Ameliorative effect of Volvariella volvacea aqueous extract (Bulliard Ex Fries) Singer on gentamicin induced renal damage. International journal of Pharmacology and Bio Sciences. 3(3): 105-117.

Umar, T. (2016). Buat Duit Dengan Mudah.my. PTS Publising House. Malaysia. ISBN13:978-967-411-852-5. 